\title{
MEDIA WAYANG MINI DALAM PEMBELAJARAN KETERAMPILAN BERBICARA BAGI PEMELAJAR BIPA A1 UNIVERSITAS EZZITOUNA TUNISIA
}

\author{
Eko Widianto \\ email: eko.widianto@umk.ac.id \\ Prodi Pendidikan Bahasa dan Sastra Indonesia, \\ Fakultas Keguruan dan Ilmu Pendidikan \\ Universitas Muria Kudus, Indonesia
}

\begin{abstract}
This study was aimed to describe using of wayang mini media for teaching of speaking comphrehensif for Indonesian for Speakers of Other Language (BIPA) student in Universite Ezzitouna, Tunisia. The data were collected via observation method and other advanced techniques. Based on the study, there were benefits of using wayang mini media in Universite Ezzitouna, Tunisia. It was not only for language learning, but also for cultural diplomatic mission. However, there were some benefits of using wayang mini media, 1)to create a communicative learning; 2) to minimalize translation methode. 3) to increase the student's vocabularies, 4) to make the student more active using the media, 5) to make a subject more valuable, and 6) to introduce Indonesian culture as a diplomatic mission. In this study, it was showed the steps of learning in speaking comphrehension by wayang mini media.
\end{abstract}

\begin{abstract}
Penelitian ini ditulis dengan tujuan untuk mendeskripsikan penggunaan media wayang mini untuk pembelajaran keterampilan berbicara bagi pemelajar BIPA tingkat A1 di Universitas Ezzitouna, Tunisia. Metode yang digunakan dalam melakukan penelitian adalah metode penelitian deskriptif kualitatif. Berdasarkan hasil penelitian, ditemukan manfaat penggunaan media wayang mini dalam pembelajaran keterampilan berbicara bagi pemelajar BIPA di Universitas Ezzitouna, Tunisia. Media wayang mini juga dapat digunakan sebagai sarana diplomasi budaya dalam aspek sosiokultural. Adapun manfaat penggunaan media pembelajaran tersebut yaitu (1) pembelajaran lebih komunikatif dan menarik; (2) meminimalkan proses translasi/terjemah dalam pembelajaran; (3) menguatkan ingatan pemelajar BIPA terhadap suatu kosakata maupun konsep karena media bersifat ikonis; (4) pemelajar lebih banyak beraktivitas dalam mengeksplorasi media; (5) bahan ajar menjadi lebih bermakna; dan (6) sarana diplomasi budaya Indonesia. Dalam penelitian ini, dikemukakan pula langkah-langkah pembelajaran yang dapat dilakukan dalam pembelajaran BIPA keterampilan berbicara menggunakan media wayang mini.
\end{abstract}

\section{PENDAHULUAN}

Bahasa Indonesia menjadi daya tarik baru di Tunisia. Kalangan akademisi mulai melirik bahasa dan budaya Indonesia sebagai pesona baru di dunia. Hal ini terbukti dengan adanya pengiriman pengajar BIPA ke Universitas Sousse selama kurun waktu dua tahun terakhir. Pada tahun 2017, Universitas Ezzitouna, Tunis, juga membuka kelas bahasa Indonesia bagi mahasiswa dan dosen. Angin segar bagi bahasa dan budaya Indonesia di Tunisia sedang berhembus kencang pada beberapa tahun terakhir. Kondisi tersebut tentu menjadi peluang sekaligus tantangan bagi bangsa Indonesia. Dari sisi peluang, bangsa Indonesia dengan mudah mendapatkan jalan untuk melalukan diplomasi kebahasaan dan kebudayaan bagi bangsa Tunisia. Sementara itu, dari sisi tantangan bangsa Indonesia harus memberikan layanan prima bagi bangsa Tunisia.

Bangsa Tunisia sebagai pemelajar BIPA tentu memiliki karakter yang khas dan berbeda dengan bangsa-bangsa lain. Karakter tersebut berkorelasi erat dengan latar 
belakang bahasa, sosial, budaya, dan geografis. Berdasarkan latar belakang bahasa, pemelajar BIPA di Tunisia merupakan dwibahasawan maupun multibahasawan. Secara umum, pemelajar BIPA di Tunisia merupakan dwibahasawan Arab dan Perancis. Hal ini menjadi satu faktor penentu keberhasilan pembelajaran BIPA di Tunisia. Secara alfabetis, bahasa Arab memiliki sistem huruf yang berbeda. Pemelajar BIPA di Tunisia cenderung memilih untuk menggunakan huruf hijaiyah dalam menulis. Selain itu, pemelajar BIPA di Tunisia juga menggunakan bahasa Arab dan Perancis dalam berkomunikasi. Kondisi tersebut juga berdampak pada proses interaksi dalam pembelajaran BIPA. Pengajar BIPA harus menentukan pilihan bahasa yang digunakan dalam interaksi pembelajaran antara bahasa Indonesia, bahasa Inggris, bahasa Arab, atau bahasa Perancis.

Pemilihan bahasa dalam proses interaksi pembelajaran BIPA di Tunisia menjadi persoalan penting. Terlebih apabila pengajar tidak menguasai bahasa Arab maupun Perancis sebagai latar belakang bahasa yang dikuasai oleh pemelajar. Proses interaksi pembelajaran dapat terganggu. Kondisi tersebut menuntut solusi dengan tepat dan terarah. Jika dipandang berdasarkan kaca mata pembelajaran bahasa asing (B2), pengajar BIPA dapat menggunakan bahasa target sebagai bahasa pengantar dalam pembelajaran (Brown 1980 dan Krashen 1985). Dalam hal ini, pengajar dapat menggunakan bahasa Indonesia dalam proses interaksi di dalam kelas. Akan tetapi, proses interaksi tersebut perlu ditunjang dengan berbagai macam cara seperti gesture dan mimik muka. Di samping itu, pengajar BIPA juga dapat memanfaatkan media pembelajaran untuk mencitrakan konsep yang sedang dipelajari (Widianto 2016).

Pembelajaran BIPA di Tunisia, khususnya Universitas Ezzitouna dihadapkan pada dua tantangan mendasar. Pertama, pemelajar Tunisia merupakan dwibahasawan Arab dan Perancis (nonbahasa Inggris). Hal ini dapat menjadi kendala proses komunikasi antara pengajar dan pemelajar. Kedua, mereka juga terbiasa belajar bahasa Indonesia atau bahasa asing lainnya dengan metode terjemah. Kedua masalah ini memengaruhi perjalanan dan perkembangan pembelajaran BIPA di Tunisia. Tantangan utama justru diakibatkan oleh kebiasaan pemelajar dalam belajar BIPA dengan metode terjemahan. Dalam pembelajaran yang terus berkembang tiap semester, mereka menuntut pengajar BIPA untuk terus menerjemahkan teks yang tengah dipelajari. Akibatnya, bahasa Indonesia dipelajari sebagai ilmu pengetahuan, bukan sebagai alat komunikasi. Padahal, pemelajar BIPA pada level pemula (A1) diharapkan mampu berkomunikasi baik lisan maupun tulisan sesuai dengan standard yang ditentukan.

Perlu dipahami bahwa pembelajaran BIPA merupakan pembelajaran bahasa kedua (B2) bagi pemelajarnya. Pembelajaran BIPA merupakan wujud nyata dari pembelajaran bahasa Indonesia sebagai bahasa asing, baik di Indonesia maupun di luar negeri. Oleh sebab itu, pembelajaran BIPA didesain dengan beragam tujuan, 
seperti tujuan diplomasi, ekonomi, pendidikan, pariwisata, dan lain sebagainya. Kondisi tersebut berpengaruh pada standar pembelajaran BIPA yang kompleks (lihat Stern 1983; Suyitno 2007; Kusmiatun 2015; dan Widianto 2015). Adapun pembelajaran BIPA di Tunisia didesain dengan tujuan pendidikan dan diplomasi budaya Indonesia.

Pendekatan sosiokultural dapat membantu pembelajaran BIPA di luar negeri. Di samping sebagai nuansa belajar bahasa Indonesia, aspek sosiokultural juga dapat digunakan sebagai sarana diplomasi budaya Indonesia di kancah internasional. Aspek sosiokultural Indonesia yang memiliki ciri khas menjadi daya tarik bagi pemelajar BIPA di luar negeri. Hal ini dapat digunakan oleh pengajar dalam pembelajaran BIPA, baik sebagai pendekatan pembelajaran maupun materi pembelajaran. Pemanfaatan aspek sosiokultural tersebut diharapkan dapat mengurai berbagai tantangan pembelajaran BIPA di luar negeri.

Senada dengan pandangan di atas, beberapa pengajar maupun praktisi BIPA telah melakukan kajian terhadap budaya guna menopang kebutuhan dalam pembelajaran. Terbukti dengan adanya beragam penelitian mengenai pemanfaatan budaya dalam pembelajaran BIPA, baik sebagai muatan dalam pembelajaran maupun materi pembelajaran (lihat Suyitno 2007; Siroj 2012; Sudaryanto 2015; dan Prasetiyo 2015). Selain itu, salah satu tujuan pembelajar asing datang ke Indonesia adalah memelajari kebudayaan. Hal ini selaras dengan karakteristik pembelajaran BIPA 122 | Jurnal Kredo Vol. 1 No. 1 Oktober 2017 sebagai pembelajaran bahasa kedua (B2) yang dirancang berdasarkan kebutuhan pembelajar (Brown 1980 dan Krashen 1985).

Pendekatan sosiokultural dan budaya dapat diwujudkan dalam bentuk media pembelajaran. Keberadaan media pembelajaran dapat membantu pelaksanaan pembelajaran BIPA. Di samping itu, media pembelajaran dapat diintegrasikan dengan model pembelajaran yang sesuai, sehingga pembelajaran BIPA tidak berjalan monoton. Pengajar juga dapat memanfaatkan media pembelajaran sebagai alat untuk menghindari metode penerjemahan di dalam kelas BIPA. Hal ini telah dilakukan dalam pembelajaran BIPA di Universitas Ezzitouna, Tunisia. Pemelajar BIPA di Universitas Ezzitouna Tunisia yang terbiasa dengan metode terjemahan pada pembelajaran sebelumnya, mulai berlatih menggunakan metode langsung dengan pemanfaatan media pembelajaran. Dengan demikian, pembelajaran BIPA menjadi lebih bermakna.

\begin{tabular}{lrr}
\multicolumn{1}{c}{ Media } & \multicolumn{2}{c}{ pembelajaran } \\
merupakan & alat-alat & grafis, \\
fotografis, atau & elektronis yang dapat \\
digunakan & pemelajar & untuk \\
menangkap, & memproses, & dan
\end{tabular}
menyusun kembali informasi visual atau verbal. Media merupakan komponen sumber belajar atau wahana fisik yang mengandung materi intruksional di lingkungan pemelajar yang dapat merangsang untuk belajar. Media pembelajaran dibagi menjadi tiga macam, yaitu media yang dapat didengar (audio), media yang dapat dilihat (video), dan media yang dapat bergerak. Media visual dikelompokkan lagi menjadi 
tiga yaitu gambar visual, garis (grafis), dan verbal (Sutirman 2013:15). Adapun manfaat media pembelajaran dalam proses belajar yaitu (1) pengajaran akan lebih menarik perhatian pemelajar sehingga dapat menumbuhkan motivasi belajar; (2) bahan ajar akan lebih jelas maknanya sehingga dapat lebih dipahami oleh pemelajar; (3) metode pembelajaran akan lebih bervariasi, tidak semata-mata komunikasi verbal; (4) pemelajar lebih banyak melakukan kegiatan belajar, sebab tidak hanya mendengarkan uraian pengajar, tetapi juga aktivitas lain seperti mengamati, melakukan, mendemonstrasikan (Sudjana \& Rivai 2010:2).

\begin{tabular}{|c|c|}
\hline $\begin{array}{l}\text { Salah } \\
\text { igunakan } \\
\text { embelajaran }\end{array}$ & $\begin{array}{l}\text { satu yang } \\
\text { adalah } \\
\text { berbasis }\end{array}$ \\
\hline
\end{tabular}
Dalam hal ini, media berbasis budaya tersebut yaitu wayang mini. Wayang mini merupakan replika dari wayang kulit di Indonesia. Dalam tulisan berjudul Bijdrage Tot De Kennis Van Het Javaansche Toonel, ahli sejarah kebudayaan Belanda Hazeau (1897) menunjukan keyakinan bahwa wayang nerupakan pertunjukan dan kesenian asli Jawa, Indonesia. Pengertian wayang dalam hal ini adalah Walulang Inukir (kulit yang diukir) dan dilihat delapan bayangannya pada klir. Dengan demikian, wayang merupakan salah satu produk budaya yang dapat digunakan sebagai sarana diplomasi melalui pembelajaran BIPA.

\section{KAJIAN TEORI}

\section{Pembelajaran BIPA}

Salah satu bagian dari pembelajaran bahasa Indonesia adalah pembelajaran bahasa Indonesia bagi penutur asing (BIPA). BIPA merupakan pembelajaran yang subjeknya ialah pembelajar asing. BIPA dipandang lebih pada faktor pembelajarnya. Orang-orang yang menjadi pembelajar BIPA adalah orang asing, bukan penutur bahasa Indonesia. Bahasa Indonesia merupakan bahasa asing bagi pembelajar, entah sebagai bahasa kedua, bahasa ketiga, keempat, atau lainnya. Pembelajaran BIPA menjadikan orang asing dapat menguasai bahasa Indonesia atau berbahasa Indonesia (Kusmiatun 2015).

Pembelajaran bahasa Indonesia bagi warga negara asing disebut sebagai pembelajaran bahasa Indonesia bagi penutur asing (BIPA). Pembelajaran BIPA menjadi salah satu bagian dalam pembelajaran bahasa. BIPA merupakan pembelajaran bahasa dengan subjek penutur asing. Pembelajaran BIPA lebih dipandang pada faktor pembelajarnya. Orang-orang yang menjadi pembelajar BIPA adalah orang asing, bukan penutur bahasa Indonesia. Bahasa Indonesia merupakan bahasa asing bagi pembelajar, baik sebagai bahasa kedua, bahasa ketiga, keempat, atau lainnya. Dengan pembelajaran BIPA, orang asing diharapkan mampu menguasai bahasa Indonesia atau berbahasa Indonesia (Kusmiatun 2015).

Pembelajaran bahasa Indonesia bagi penutur asing (BIPA) mulai dirintis sejak tahun 1990-an di Indonesia. Kemudian, pada tahun 1999 dibentuk tim khusus untuk menangani BIPA. Penyelenggaraan kegiatan pembelajaran BIPA dilandasi oleh pertimbangan bahwa 
pada era global, posisi bahasa Indonesia dalam hubungan dengan dunia internasional makin penting dan potensial. Dengan demikian, besar harapan bahasa Indonesia untuk menjadi jembatan dalam berbagai hubungan kenegaraan, karena bagaimanapun juga bahasa merupakan alat yang penting, terutama sebagai alat berkomunikasi (badanbahasa.kemdikbud.go.id 2016).

Pembelajaran BIPA bukan fenomena baru dalam perkembangan bahasa Indonesia. Berdasarkan data yang tercatat oleh Depdiknas, terdapat 219 perguruan tinggi atau lembaga di 40 negara yang telah menyelenggarakan program pembelajaran BIPA. Adapun negaranegara yang tercatat sebagai penyelenggara pembelajaran BIPA adalah Australia, Austria, Kanada, Belanda, Polandia, Cekoslovakia, Denmark, Perancis, Jerman, Italia, Rusia, Selandia Baru, Norwegia, Swedia, Swiss, Inggris, Vatikan, Amerika, Suriname, India, Jepang, China, Malaysia, Papua Nugini, Arab Saudi, Singapura, Korea Selatan, Filipina, Vietnam, Thailand, dan Mesir (Kusmiatun 2015:10).

Terkait dengan hal tersebut, bahasa Indonesia hingga pada saat ini telah diajarkan kepada orang asing di berbagai lembaga, baik di dalam maupun di luar negeri. Di dalam negeri pada saat ini tercatat tidak kurang dari 45 lembaga yang telah mengajarkan bahasa Indonesia bagi penutur asing (BIPA), baik di perguruan tinggi maupun di lembaga-lembaga kursus. Sementara itu, di luar negeri, Pengajaran BIPA telah dilakukan oleh sekitar 36 negara di dunia dengan jumlah lembaga tidak kurang dari 130 buah, yang terdiri atas perguruan tinggi, pusat-pusat kebudayaan asing, KBRI, dan lembaga-lembaga kursus (badanbahasa.kemdikbud.go.id 2016).

Kemajuan yang telah dicapai oleh bangsa Indonesia di tengah era global sekarang ini, peran Indonesia dalam pergaulan antarbangsa juga telah menempatkan bahasa Indonesia sebagai salah satu bahasa yang dipandang penting di dunia. Hal itu juga ditunjang oleh posisi Indonesia dalam percaturan dunia yang semakin hari semakin penting, terutama melalui peranannya, baik dalam turut serta menyelesaikan konflik-konflik politik di berbagai kawasan maupun karena posisi geografis Indonesia yang terletak dalam lintas laut yang sangat strategis. Kenyataan seperti itu telah menyebabkan banyak orang asing yang tertarik dan berminat untuk mempelajari bahasa Indonesia sebagai alat untuk mencapai berbagai tujuan, baik tujuan politik, perdagangan, seni-budaya, maupun wisata.

\begin{tabular}{ccr}
\multicolumn{2}{c}{ Pengajaran BIPA di samping } \\
merupakan media
\end{tabular} menyebarluaskan bahasa Indonesia, juga merupakan media untuk menyampaikan berbagai informasi tentang Indonesia, termasuk memperkenalkan masyarakat dan budaya Indonesia. Dengan demikian, orang asing yang mempelajari bahasa Indonesia akan semakin memahami masyarakat dan budaya Indonesia secara lebih komprehensif. Pemahaman itu pada gilirannya dapat meningkatkan rasa saling pengertian dan saling menghargai sehingga makin meningkatkan pula persahabatan dan kerja sama antarbangsa. 
Pengajar BIPA yang baik akan menjadi model bagi muridmuridnya. Pengajar yang baik akan berupaya memanfaatkan segala fasilitas dan peluang yang ada dalam membuat kegiatan belajarmengajarnya berhasil guna. Berbagai aspek-aspek turut terlibat di dalam upaya membuat pembelajaran BIPA itu berhasil dengan baik. Aspek-aspek sosial budaya mempunyai peranan yang amat penting dalam pembelajaran BIPA. Peranannya itu terutama dapat menghindarkan pembelajar bahasa dari kemungkinan terjadinya benturan budaya (cultural shock) ketika berkomunikasi dengan penutur asli. Keberadaan aspekaspek pembelajaran BIPA berperan dan didudukkan secara fungsional dan proporsional dalam kebijakan penyelenggaraan BIPA. (1) latar belakang individu pemebelajar, (2) motivasi pembelajar, (3) pengelolaan kelas (dalam dan luar) melalui elaborasi materi dan kolaborasi kegiatan, (4) lingkungan penggunaan bahasa di masyarakat, dan (5) pengalaman faktual (pajanan berbahasa dan problematika). Pembelajaran BIPA memerlukan upaya yang beraneka, seperti halnya pembelajaran bahasa asing lainnya.

Pembelajaran BIPA dapat disikapi sebagai sebuah sistem yang terdiri atas sejumlah komponen pendukung, yaitu komponen instruksional dan non-instruksional. Hubungan dan interaksi interaksi fungsional antar komponen tersebut menciptakan proses dan hasil belajar (Winkel 1987). Dalam pembelajaran BIPA keberadaan dan peran pembelajar merupakan komponen yang menonjol. Dapat dikatakan, komponen pembelajar ini yang membedakan secara signifikan antara pembelajaran BIPA dengan pembelajaran bahasa Indonesia yang lain. Sosok pembelajar BIPA sebagai penutur asing bahasa Indonesia memiliki karakteristik tertentu, terutama tampak pada (1) ciri personal, (2) latar belakang sosial, (3) bidang (4) pengetahuan / kemampuan, (5) minat, (6) tujuan belajar, (7) strategi belajar, dan (8) waktu belajar. Keberadaan dan kondisi pembelajar tersebut berimplikasi pada peran serta hubungan dengan komponen instruksional lain dalam perwujudan pembelajaran BIPA. Lebih lanjut, karakteristik pembelajar juga menjadi bahan yang harus dipertimbangkan sebagai variabel yang berpengaruh dan turut menentukan dalam pembelajaran BIPA (Alwasilah 1998).

Pembelajaran BIPA memiliki target tertentu, yaitu membentuk pembelajar berkemampuan berbahasa secara wajar. Dalam pengertian yang lebih luas, kewajaran ini terkait dengan hal-hal lain, termasuk didalamnya budaya yang senantiasa melekat dalam substansi bahasa, karena itu di samping persoalan karakteristik personal pembelajar, persoalan budaya juga ikut terlibat dalam penciptaan pembelajaran BIPA (Stern, 1987). Dikatakan demikian, karena pertimbangan tersebut sekaligus akan menjadi wahana dan kebutuhan pembelajar dalam berkomunikasi secara langsung dan faktual.

Pembelajaran BIPA sebagai sebuah program, tentu memiliki pijakan yang jelas sebagaimana tampak pada prinsip dasar pembelajaran pada umumnya. 
Demikian pula, sebagai bentuk pembelajaran bahasa, pembelajaran BIPA juga didasarkan pada kaidah konseptual pembelajaran bahasa asing yang menjadi landasan pendekatannya. Kaidah konseptual yang dimaksud terutama bersumber pada teori bahasa dan teori pembelajaran bahasa (Spolsky 1980; Stern 1987). Secara aspektual, spesifikasi pembelajaran BIPA antara lain tampak pada (1) tujuan pembelajaran,

(2) sasaran pembelajaran, (3) tatanan materi, (4) pemilihan metode, (5) pemanfaatan sumber/media, (6) kegiatan pembelajaran, (7) evaluasi pembelajaran, dan (8) problematika pembelajarannya. Mengingat perwujudan aspek-aspek pembelajaran tersebut merupakan hal yang cukup kompleks, maka diperlukan landasan konseptual pembelajaran BIPA yang jelas. Tanpa kejelasan acuan sangat dimungkinkan arah pembelajaran BIPA menjadi bias dan berpengaruh pada negatif pada produktivitasnya.

\begin{tabular}{lrr}
\multicolumn{2}{c}{ Gambaran } & pembelajaran \\
BIPA tersebut & menunjukkan \\
pembelajaran BIPA & merupakan \\
perihal yang & kompleks.
\end{tabular}
Kekomplekannya bukan saja tampak pada komponen instruksional, melainkan juga pada keterkaitannya dengan faktor lain dalam perwujudan pembelajaran BIPA. Untuk mewujudkan pembelajaran BIPA yang memadai perlu mempertimbangkan hal-hal tersebut secara seksama dan menyeluruh. Ditinjau dari segi pola organisasi dan pengelolaan, pembelajran BIPA hendaknya (1) mampu menumbuhkembangkan motivasi belajar, dan (2) mampu memberikan kemudahan bagi pembelajar dalam

126 | Jurnal Kredo Vol. 1 No. 1 Oktober 2017 menguasai bahasa indonesia secara wajar (Zulaeha 2016). Sasaran tersebut dipetakan dan diwujudkan dalam sebuah bentuk atau model pembelajaran BIPA yang spesifik dan jelas.

Dilihat dari segi kegiatannya, pembelajaran BIPA merupakan proses pemolaan perilaku belajar yang mengarah pada pembangkitan dan pengkondisian motivasi pembelajar dalam berbahasa Indonesia. Hal esensial yang perlu mendapatkan prioritas dan perhatian khusus adalah bagaimana mengembangkan pembelajaran sedemikian rupa, sehingga dapat mengkondisikan dan memberikan kemudahan kepada pembelajar untuk mau dan mampu berbahasa Indonesia secara wajar (Zulaeha 2016).

Upaya Tersebut memerlukan suatu pengelolaan pembelajaran secara khusus, terutama dengan memperhatikan mekanisme belajar yang efektif, accomodative, kondusif, dan berorientasi pada kebutuhan / kepentingan pembelajar. Artinya, perencanaan dan proses pembelajaran hendaknya dikembangkan secara sistematis, seksama, serta dijangkaukan untuk menumbuhkembangkan motivasi dan kesadaran pembelajar pada target pembelajaran yang jelas. Di samping itu, bertitik tolak pada keberadaan bahasa sebagai subsistem perilaku, kiranya perlu pula dikembangkan pola pembelajaran yang dapat menciptakan mood belajar ke arah pembiasaan berbahasa Indonesia dalam bentuk pengalaman faktual. Dalam penguasaan bahasa asing, pengalaman faktual memiliki peranan amat penting, terutama dalam perwujudan input dan pencapaian output (Krashen 1985). 
Keberadaan aspek-aspek pembelajaran BIPA berperan dan didudukkan secara fungsional dan proporsional dalam kebijakan penyelenggaraan BIPA. (1) latar belakang individu pemebelajar, (2) motivasi pembelajar, (3) pengelolaan kelas (dalam dan luar) melalui elaborasi materi dan kolaborasi kegiatan, (4) lingkungan penggunaan bahasa di masyarakat, dan (5) pengalaman faktual (pajanan berbahasa dan problematika). Semuanya mengarah kepada sikap pembelajar dalam menguasai bahasa Indonesia secara wajar sebagai wujud output pembelajaran.

Kelas pembelajaran BIPA dapat dibedakan menjadi dua bagian, yaitu kelas dalam dan kelas luar. Kelas dalam yang dimaksud, identik dengan pengertian kelas pembelajaran sebagaimana lazimnya. Dalam pengertian ini kelas tersebut tentu berupa ruang yang didalamnya terdapat pengajar, pembelajar, dan komponen pembelajaran lain, serta mekanisme belajar yang diatur dalam pengelolaan kelas, sedangkan kelas luar mengacu pada pengertian pengelolaan pembelajaran yang dilakukan di luar (di luar kelas dalam). Kegiatan kelas luar ini dalam penegrtian khusus juga disebut kegiatan tutorial meskipun kegiatan kelas luar tidak selalu berupa kegiatan tutorial.

Gambaran pembelajaran BIPA yang dilakukan di kelas dalam dikemukakan oleh Zulaeha (2016), antara lain dapat dipahami melalui penjelasan pada hal-hal spesifik berikut.

(1) Kapasitas kelas terdiri atas 5 sampai 10 orang (pembelajar)
(2) Kelas yang kecil dimaksudkan untuk kepentingan intensitas perhatian, penggiliran latihan, dan penanganan kasus.

(3) Dengan kelas yang kecil diasumsikan akan lebih mudah bagi pengajar dalam mengelola kelas secara kondusif.

(4) Pembelajaran dilakukan secara terpadu, maksudnya sajian materi keterampilan berbahasa, kosakata, dan catatan budaya tidak dilakukan secara terpisah.

(5) Kompetensi berbahasa yang dibentuk melalui kelas dalam lebih diarahkan pada penguasaan dan pemantapan kaidah dasar.

(6) Bahasa pengantar yang digunakan dalam pembelajaran sedapat mungkin bahasa target. Bahasa ibu pembelajar hanya digunakan jika benarbenar diperlukan.

Pengajar merupakan tim teaching yang selalu berkoordinasi dan berkolaborasi satu dengan yang lain, termasuk dengan tutor dan pembelajar.

Kusmiatun (2015:1) juga menambahkan bahwa visi BIPA adalah pemberdayaan pengajar dan pembelajarnya melalui pengajaran yang berkelanjutan, terstruktur, dan sistematis dalam pengembangan secara profesional. Selain itu, BIPA juga menjadi penguatan bagi identitas nasional. Bahasa menunjukkan bangsa. Bahasa Indonesia adalah salah satu lambang identitas negara. BIPA merupakan suatu jalan untuk mengenalkan sekaligus menguatkan identitas bangsa, yakni bahasa Indonesia. Visi lainnya adalah BIPA akan menjadi dukungan bagi pengajaran bahasa dan budaya Indonesia secara global. 
Di dalam pengajaran BIPA, budaya tidak terlepaskan. Keduanya, bahasa dan budaya menjadi bagian erat dan sailing mendukung sebagai sebuah program pengajaran.

Pembelajaran bahasa Indonesia bagi penutur asing (BIPA) dilaksanakan dengan tujuan yang berbeda-beda. Hal ini disebabkan pembelajar BIPA memiliki motivasi berbeda-beda pada saat mempelajari bahasa Indonesia. Tujuan pembelajaran BIPA yaitu membentuk pembelajar berkemampuan berbahasa secara wajar. Kewajaran ini terkait dengan hal-hal lain, termasuk di dalamnya budaya yang senantiasa melekat dalam substansi bahasa. Selain persoalan karakteristik personal pembelajar, persoalan budaya juga ikut terlibat dalam penciptaan pembelajaran BIPA (Stern 1987). Terutama ketika pembelajaran BIPA diselenggarakan di Indonesia. Pertimbangan sosial budaya menjadi sangat penting. Pembelajaran tidak hanya mengajarkan cara berkomunikasi. Akan tetapi, pembelajaran juga berfungsi sebagai penanaman wawasan mengenai sosial dan budaya Indonesia. Dengan demikian, pembelajaran BIPA akan lebih bermakna.

Pembelajaran BIPA dapat dilihat sebagai sebuah sistem yang terdiri atas sejumlah komponen pendukung, yaitu komponen instruksional dan noninstruksional. Hubungan dan interaksi fungsional antarkomponen tersebut akan menciptakan proses belajar mengajar dan hasil belajar. Dengan demikian, pembelajaran BIPA merupakan suatu kegiatan kompleks yang memiliki banyak komponen dan fungsi (Winkel 1987).

128 | Jurnal Kredo Vol. 1 No. 1 Oktober 2017
Peran pembelajar dalam pembelajaran BIPA merupakan komponen yang menonjol. Dapat dikatakan, komponen pembelajar ini yang membedakan secara signifikan antara pembelajaran BIPA dengan pembelajaran bahasa Indonesia lainnya. Sosok pembelajar BIPA sebagai penutur asing bahasa Indonesia memiliki karakteristik tertentu, terutama pada (1) ciri personal; (2) latar belakang asal; (3) bidang; pengetahuan/kemampuan; (5) minat; (6) tujuan belajar; (7) strategi belajar; dan (8) waktu belajar. Keberadaan dan kondisi pembelajar tersebut akan berimplikasi pada peranan serta hubungannya dengan komponen instruksional lain. Karakteristik pembelajar juga menjadi bahan yang harus dipertimbangkan sebagai variabel yang berpengaruh dan ikut menentukan dalam pembelajaran BIPA (Stern 1987).

Berdasarkan beberapa pendapat ahli di atas, dapat disimpulkan bahwa pembelajaran bahasa Indonesia bagi penutur asing (BIPA) adalah salah satu dari bagian pembelajaran bahasa. Akan tetapi, pembelajaran BIPA memiliki subjek pembelajar penutur asing. Artinya, pembelajar merupakan warga negara asing yang belajar bahasa Indonesia. Pembelajaran BIPA didesain berdasarkan tujuan yang ingin dicapai oleh pembelajar, seperti kepentingan pariwisata, ekonomi, pendidikan, dan lain sebagainya. Pembelajar BIPA juga berasal dari latar belakang bahasa, etnis, dan sosial yang beragam. Oleh karena itu, pembelajaran BIPA harus didesain dengan tepat agar dapat berjalan dengan optimal. 
Berdasarkan prinsip pengajaran bahasa menurut Rivers dalam Rahmina (2002:8), pengajaran BIPA harus memperhatikankan aspek-aspek (1) proporsi materi keterampilan dan nonketerampilan berbahasa; (2) pertimbangan lintas budaya pembelajar dan pengajar; (3) karakteristik pembelajar; (4) tujuan pembelajar belajar BIPA; (5) penentuan penggunaan metode pembelajaran yang sesuai dengan tujuan; (6) penentuan penggunaan media pembelajaran yang efektif; dan (7) penentuan penggunaan alat evaluasi pembelajaran yang tepat.

Kusmiatun (2015:21-22) menguatkan pendapat sebelumnya mengenai prinsip pembelajaran BIPA. Kusmiatun mengemukakan prinsip dasar pembelajaran BIPA sebagai berikut.

1) Prinsip berjenjang, merupakan sebuah prinsip untuk mencermati beberapa hal yang berjenjang dalam pembelajaran BIPA. Setidaknya ada tiga hal berjenjang yang harus diperhatikan oleh pengajar BIPA. Pertama, pembelajaran harus dimulai dari hal-hal yang konkret dan bergeser ke hal-hal yang abstrak, hal-hal yang global ke hal yang detail. Pembelajar akan lebih mudah mencerna sesuatu yang daoat ditunjukkan secara nyata daripada yang tidak nyata. Kosakata seperti meja, kursi, nasi, apel akan dapat dipahami pembelajar dengan lebih mudah daripada kata adil, jujur, kebangkitan, dan lain sebagainya. Kedua, isi materi yang diberikan haruslah berkesinambungan. Dalam beberapa pertemuan pembelajaran, isi materi harus berkaitan. Ketiga, beban materi pembelajarn BIPA harus diajarkan dari yang sederhana menuju materi yang lebih kompleks.

2) Prinsip prioritas, dalam pembelajaran BIPA, seorang pengajar harus mengetahui prioritas pembelajaran yang dibutuhkan oleh pembelajar. Pembelajar dasar sangat membutuhkan keterampilan berbahasa berbicara dan mendengarkan. Kedua keterampilan itu lebih diprioritaskan daripada keterampilan membaca dan menulis.

3) Prinsip korektisitas, pembelajaran BIPA biasanya diberikan kepada pembelajar dewasa atau anak-anak yang tidak di masa kanak-kanak. Kesalahan yang dilakukan oleh mereka merupakan sarana untuk pemahaman dan belajar. Pengajar tidak hanya menyalahkan tetapi harus memberikan pembetulannya. Koreksi atas kesalahan yang dilakukan dijadikan sebagai ajang belajar, sehingga pembelajar akan bersikap kritis dan dapat belajar dari kesalahannya.

Teori-teori di atas akan digunakan sebagai landasan untuk mengkaji setiap variabel dalam penelitian ini. Dengan teori-teori tersebut, peneliti dapat menggunakannya sebagai prinsipprinsip dan pendekatan dalam melakukan penelitian. Selain itu, teori-teori tersebut juga menjadi dasar penelitian dan menjadi 
landasan keilmuan. Dengan demikian, hasil dari penelitian ini menjadi valid dan membawa kebermanfaatan dalam perkembangan ilmu pengetahuan.

Sebagai pembelajaran bahasa Indonesia bagi penutur asing, posisi pembelajaran tata bahasa menjadi penting. Hal ini disebabkan tata bahasa memiliki peran penting dalam penguasaan bahasa seseorang. Tata bahasa menjadi salah satu indikator sentral yang dapat digunakan sebagai ukuran penguasaan bahasa seseorang. Dengan demikian, pembelajaran tata bahasa dalam BIPA perlu diperhatikan dengan saksama.

Secara sistem, tata bahasa Indonesia dengan bahasa asing memiliki perbedaan. Jika dianalogikan dengan bahasa Inggris, tata bahasa Indonesia dengan Inggris sangat berbeda. Dalam bahasa Inggris, dikenal istilah tenses. Sementara itu, tenses tidak digunakan dalam bahasa Indonesia. Demikian pula dalam bahasa Arab, dikenal fi'il madhi (tindakan lampau) dan fi'il mudhari' (tindakan sekarang dan masa depan) sebagai penanda waktu. Hal ini menunjukkan adanya karakteristik yang berbeda dalam sistem tata bahasa Indonesia.

Secara empiris, pembelajaran tata bahasa dapat diintegrasikan dengan empat keterampilan berbahasa. Pembelajaran tata bahasa digunakan secara integratif dalam pembelajaran empat keterampilan berbahasa. Akan tetapi, pembelajaran tata bahasa juga dapat pula diajarkan secara terpisah dari empat keterampilan berbahasa. Artinya, tata bahasa menjadi satu mata pelajaran/kuliah yang dapat diambil

130 | Jurnal Kredo Vol. 1 No. 1 Oktober 2017 oleh pembelajar BIPA. Hal ini bertujuan untuk memfokuskan pembelajaran tata bahasa agar lebih komprehensif dan terarah.

Pembelajaran tata bahasa dalam BIPA tidak luput dari persoalan. Salah satu persoalan yang kerap muncul adalah kesenjangan antara sistem bahasa pertama yang dikuasai oleh pembelajar dengan sistem bahasa Indonesia. Untuk mengatasi persoalan tersebut, aspek sosiokultural dapat digunakan sebagai pendekatan pembelajaran tata bahasa Indonesia. Aspek sosiokultural dapat digunakan sebagai senjata pengurai kesenjangan yang terjadi antara bahasa pertama pembelajar dengan bahasa Indonesia.

Sementara itu, pengajaran BIPA di luar negeri dapat dilakukan melalui beberapa program. Salah satu program pengajaran BIPA di luar negeri adalah Program SAME BIPA Dikti yang diselenggarakan oleh Kementerian Riset, Teknologi dan Pendidikan Tinggi. Direktorat Jenderal Sumber Daya Iptek dan Pendidikan Tinggi telah mengembangkan Program SAME (Scheme for Academic Mobility and Exchange) BIPA (Bahasa Indonesia Penutur Asing). Program ini merupakan program pengiriman dosen ke berbagai perguruan tinggi luar negeri yang bertugas khusus dalam misi kebangsaan sebagai pengajar bahasa, seni, atau budaya Indonesia atas permintaan dari Kedutaan Besar Repulik Indonesia di luar negeri. Program ini juga menawarkan kepada perguruan tinggi yang sudah memiliki kerja sama dengan perguruan tinggi di luar negeri termasuk untuk mengirim dosen BIPA mengajar di negara mitra. 
Bagi perguruan tinggi yang dosennya berminat untuk mengikuti kegiatan tersebut kami mohon untuk segera mengisi form SAME BIPA dan melengkapi berkas permohonan sebagaimana yang dipersyaratkan dalam Pedoman Penyelenggaraan Program SAME BIPA Tahun 2016 yang dapat diunduh di laman sdid.dikti.go.id (2016). Selain itu, lampiran-lampiran yang mendukung penawaran tersebut juga disertakan seperti surat penawaran program SAME, pedoman, maupun form keikutsertaan. Kegiatan SAME BIPA dimulai dengan pengiriman berkas. Apabila masuk kualifikasi dan lolos, tahap selanjutnya adalah tes wawancara dan microteaching. Setelah itu apabila peserta dinyatakan lolos maka wajib mengikuti pembekalan keberangkatan yang diadakan oleh Dikti.

Pengajar bahasa Indonesia bagi penutur asing (BIPA) yang mengikuti program SAME BIPA Dikti dituntut memiliki modal pengetahuan dan wawasan kebudayaan Indonesia. Hal ini menjadi modal penting dalam mengelola pembelajaran BIPA di luar negeri. Pembelajaran BIPA tidak berhenti pada persoalan membelajarkan bahasa Indonesia bagi penutur asing. Akan tetapi, muatan-muatan budaya dalam pembelajaran merupakan esensi yang perlu diperhatikan.

Banyak kendala yang sering dijumpai di lapangan berkaitan dengan pelaksanaan pembelajaran BIPA di luar negeri yang diadakan oleh Dikti dalam program SAME BIPA. Budaya Indonesia jarang diberikan kepada para pembelajar asing secara praktis. Para pengajar
BIPA hanya memberikan materi budaya Indonesia secara teoretis. Padahal, BIPA adalah paket yang mengajarkan bahasa dan budaya Indonesia di dalamnya yang diintegrasikan dalam materi ajar. Untuk itu, proses seleksi terhadap para pengajar BIPA yang akan dikirim ke luar negeri harus dilakukan dengan saksama. Proses seleksi tersebut menentukan kualitas pengajar yang diterjunkan di berbagai penjuru dunia. Dalam proses seleksi, perlu diketahui kompetensi yang dimiliki oleh pengajar BIPA yang akan ditugaskan di luar negeri.

Selain mengenalkan bahasa Indonesia kepada warga negara asing, pengajar BIPA juga memiliki tanggung jawab besar dalam memperkenalkan budaya Indonesia pada dunia internasional. Pengajaran BIPA merupakan bagian penting dalam misi diplomasi budaya di kancah internasional. Bahkan, pengajar BIPA dapat dikatakan sebagai diplomat bahasa di kancah internasional (Widianto 2016). Pengajaran BIPA merupakan bagian penting dalam misi diplomasi budaya di dunia internasional. Adapun yang berperan aktif dalam misi tersebut adalah pengajar BIPA.

Wujud budaya yang ada di masyarakat terbagi atas tiga jenis, yakni gagasan, aktivitas, dan artefak (Koentjaraningrat 2015:15). Gagasan merupakan suatu wujud kebudayaan dari ide-ide, norma-norma, dan nilainilai. Aktivitas adalah wujud kebudayaan berupa kelakuan berpola dari manusia dalam masyarakat. Artefak merupakan wujud kebudayaan berupa benda-benda hasil karya manusia. Sementara itu, secara khusus budaya lokal diartikan 
sebagai ciri khas budaya yang dimiliki suatu masyarakat lokal. Budaya tersebut menjadi ciri khusus yang dimiliki suatu kelompok masyarakat, seperti rumah joglo, keris, sekaten, dugderan, ngaben, kirab, dan lain sebagainya.

Budaya dapat digunakan sebagai pendekatan dan materi dalam pembelajaran BIPA. Beberapa pengajar maupun praktisi BIPA telah melakukan kajian terhadap budaya guna menopang kebutuhan dalam pembelajaran. Terbukti dengan adanya beragam penelitian mengenai pemanfaatan budaya dalam pembelajaran BIPA, baik sebagai muatan dalam pembelajaran maupun materi pembelajaran (lihat Suyitno 2007; Siroj 2012; Sudaryanto 2015; dan Prasetiyo 2015). Selain itu, salah satu tujuan pembelajar asing datang ke Indonesia adalah memelajari kebudayaan. Hal ini selaras dengan karakteristik pembelajaran BIPA sebagai pembelajaran bahasa kedua (B2) yang dirancang berdasarkan kebutuhan pembelajar (Brown 1980 dan Krashen 1985).

\section{Perbedaan Pengajaran BIPA di Dalam Negeri dan di Luar Negeri}

Pada intinya mengajar BIPA di dalam maupun di luar negeri tidak memiliki perbedaan yang siginifikan meskipun ada beberapa faktor yang dapat berpengaruh terhadap proses pembelajarannya. Perbedaan yang dapat dibandingkan dalam dari segi pengajarnya, teknik pembelajarannya, dan karakteristik pembelajarnya (Istanti 2016).

Tabel 1. Perbandingan Pembelajaran BIPA

\begin{tabular}{|c|c|}
\hline $\begin{array}{l}\text { Pembelajaran BIPA } \\
\text { di Dalam Negeri }\end{array}$ & $\begin{array}{l}\text { Pembelajaran BIPA } \\
\text { di Luar Negeri }\end{array}$ \\
\hline \multirow[t]{2}{*}{$\begin{array}{l}\text { Seorang pengajar BIPA di dalam } \\
\text { negeri dapat mengajarkan materi } \\
\text { pada tiap aspek aja (menyimak, } \\
\text { berbicara, membaca, dan menulis). } \\
\text { para pengajar BIPA dapat } \\
\text { berkoordinasi dengan pengajar } \\
\text { yang lain dalam pembagian materi. }\end{array}$} & $\begin{array}{l}\text { Seorang pengajar BIPA di luar } \\
\text { negeri harus menguasai semua } \\
\text { materi, kompetensi, keterampilan } \\
\text { berbahasa Indonesia, serta budaya } \\
\text { tentang Indonesia (baik teori dan } \\
\text { praktiknya) }\end{array}$ \\
\hline & $\begin{array}{l}\text { Pengajar BIPA di luar negeri } \\
\text { harus mumpuni di semua bidang. }\end{array}$ \\
\hline $\begin{array}{l}\text { Teknik pembelajaran BIPA di } \\
\text { dalam negeri dengan metode } \\
\text { langsung (berhubungan dengan } \\
\text { masyarakat Indonesia) akan } \\
\text { mempercepat pemahaman dan } \\
\text { penguasaan bahasa Indonesia bagi } \\
\text { para pembelajar BIPA. Meskipun }\end{array}$ & $\begin{array}{l}\text { Teknik pembelajaran BIPA secara } \\
\text { tidak langsung yang hanya } \\
\text { bersumber dari media } \\
\text { pembelajaran yang digunakan } \\
\text { (video atau rekaman percakapan) } \\
\text { atau tutuan dari pengajar BIPA } \\
\text { saja akan membuat pemahaman }\end{array}$ \\
\hline
\end{tabular}

132 | Jurnal Kredo

Vol. 1 No. 1 Oktober 2017 


\begin{tabular}{|c|c|}
\hline $\begin{array}{l}\text { bahasa asing digunakan oleh } \\
\text { pengajar, namun lingkungan dari } \\
\text { para native speaker akan snagat } \\
\text { berpengaruh } \\
\text { perkembangan bahasa Indonesia } \\
\text { para penutur asing (BIPA) }\end{array}$ & $\begin{array}{l}\text { dan penguasaan kosakata para } \\
\text { pembelajar BIPA kurang } \\
\text { maksimal. Bahasa asing masih } \\
\text { mendominasi dalam penyampaian } \\
\text { materi tersebut. }\end{array}$ \\
\hline $\begin{array}{l}\text { Karakteristik pembelajar BIPA di } \\
\text { dalam negeri lebih beragam karena } \\
\text { biasanya mereka berasal dari } \\
\text { negara yang berbeda. Perbedaan } \\
\text { asal pembelajar inilah yang } \\
\text { menyebabkan beragam jenis } \\
\text { budaya yang mereka miliki } \\
\text { beragam pula. Maka pengajar } \\
\text { BIPA harus dapat } \\
\text { mengintegrasikan jenis budaya } \\
\text { yang mereka miliki dalam contoh } \\
\text { materi ajar atau perbandingan } \\
\text { budaya Indonesia dengan budaya } \\
\text { masing-masing pembelajar. }\end{array}$ & $\begin{array}{l}\text { Karakteristik pembelajar BIPA } \\
\text { pada umumnya homogen. Hal } \\
\text { tersebut dikarenakan mereka } \\
\text { tinggal dalam satu negara yang } \\
\text { sama. Seorang pengajar BIPA } \\
\text { akan lebih mudah dalam } \\
\text { memberikan materi atau } \\
\text { menyampaikan/mengenalkan } \\
\text { budaya Indonesia. Pengajar BIPA } \\
\text { bagi pembelajar yang satu } \\
\text { karakteristik dapat menyiasati } \\
\text { proses pembelajaran BIPA dengan } \\
\text { secara keseluruhan mengajarkan } \\
\text { budaya Indonesia dengan bisa } \\
\text { membandingkan budaya yang ada } \\
\text { di negara tersebut (komparasi). }\end{array}$ \\
\hline
\end{tabular}

\section{Media pembelajaran berbasis budaya dalam BIPA}

\begin{tabular}{lrr}
\multicolumn{1}{c}{ Media } & \multicolumn{2}{r}{ pembelajaran } \\
merupakan & alat-alat grafis, \\
fotografis, atau elektronis yang dapat \\
digunakan & pemelajar untuk \\
menangkap, & memproses, dan
\end{tabular} menyusun kembali informasi visual atau verbal. Media merupakan komponen sumber belajar atau wahana fisik yang mengandung materi intruksional di lingkungan pemelajar yang dapat merangsang untuk belajar. Media pembelajaran dibagi menjadi tiga macam, yaitu media yang dapat didengar (audio), media yang dapat dilihat (video), dan media yang dapat bergerak. Media visual dikelompokkan lagi menjadi tiga yaitu gambar visual, garis (grafis), dan verbal (Sutirman 2013:15).

Adapun manfaat media pembelajaran dalam proses belajar yaitu (1) pengajaran akan lebih menarik perhatian pemelajar sehingga dapat menumbuhkan motivasi belajar; (2) bahan ajar akan lebih jelas maknanya sehingga dapat lebih dipahami oleh pemelajar; (3) metode pembelajaran akan lebih bervariasi, tidak semata-mata komunikasi verbal; (4) pemelajar lebih banyak melakukan kegiatan belajar, sebab tidak hanya mendengarkan uraian pengajar, tetapi juga aktivitas lain seperti mengamati, melakukan, mendemonstrasikan (Sudjana \& Rivai 2010:2). 
Sesuai dengan kajian yang telah dilakukan, konsep mengenai aspek-aspek sosial budaya, meskipun batasan-batasannya tidak tegas benar dapat dibedakan ke dalam aspekaspek sosial dan aspek-aspek budaya. Berkenaan dengan hal itu, konsep mengenai aspek-aspek sosial yang dimaksud dikemukakan Mustakim (2010) sebagai berikut.

(1)Tempat komunikasi berlangsung

(2)Tujuan komunikasi

(3)Peserta komunikasi, yang meliputi status sosial, pendidikan, usia, dan jenis kelaminnya.

(4)Hubungan peran dan hubungan sosial di antara peserta komunikasi, termasuk relasi, adatidaknya hubungan kekerabatan, dan tingkat keakraban peserta komunikasi.

(5)Topik pembicaraan

(6)Situs komunikasi

(7)Waktu

berlangsungnya komunikasi

(8)Domain atau ranah pembicaraan

(9)Saran komunikasi yang digunakan

(10)Ragam bahasa atau variasi bahasa

(11)Penggunaan sistem sapaan

(12)Peristiwa tutur (misalnya kuliah, pesta ulang tahun, upacara perkawinan, dan sebagainya.

Berdasarkan hasil penelitian yang dilakukan oleh Mustakim yang kemudian dikutip oleh Zulaeha (2016), dikemukakan bahwa belum semua buku bahan ajar BIPA menyajikan materi atau informasi tentang aspek-aspek sosial budaya masyarakat Indonesia. Hal itu terbukti dari 43 judul buku BIPA yang diamati, ternyata yang menyajikan materi tentang aspekaspek sosial budaya masyarakat

134 | Jurnal Kredo Vol. 1 No. 1 Oktober 2017
Indoensia hanya 24 buah atau 56\%. Sisanya, sebanyak 19 judul buku atau $44 \%$ tidak menyajikan materi tersebut. Meskipun demikian, dari 19 judul buku BIPA yang tidak menyajikan materi sosial budaya itu, 8 judul di antaranya (42\%), atau $19 \%$ dari jumlah seluruh buku, tetap menyajikan informasi tentang aspekaspek sosial budaya itu. Hanya saja, penyajiannya itu terbatas pada teksteks bacaan saja. Selebihnya, 11 judul buku yang lain (58\%), atau $26 \%$ dari jumlah seluruh buku, sama sekali tidak menyinggung masalah sosial budaya yang berlaku di dalam masyarakat Indonesia.

Pencantuman materi tentang aspek sosial budaya masyarakat Indonesia di dalam buku-buku tersebutm kecuali dalam buku Spoken Indonesian: A Course in indonesian National Language yang ditulis Anderson, hampir seluruhnya tidak diintegrasikan di dalam teks materi ajar. Pencantuman itu umumnya hanya dilakukan di dalam tajuk Catatan Budaya, sedangkan dalam beberapa buku yang lain pencantumannya di dalam tajuk Keterangan. Kenyataan itu menunjukkan bahwa materi tentang aspek-aspek sosial-budaya oleh para penulis buku BIPA - hanya dianggap sebagai pelengkap. Jadi, materi itu belum dipandang sabagai bagian yang penting di dalam pembelajaran BIPA. Padahal, tanpa pengetahuan mengenai aspek-aspek sosial budaya itu mustahil pembelajar BIPA dapat berkomunikasi secara baik dan benar dengan menggunakan bahasa Indonesia.

Kenyataan tersebut patut disayangkan. Meskipun demikian, hal itu masih lebih baik daripada tidak mencantumkan informasi 
tentang aspek-aspek sosial budaya sama sekali. Paling tidak, meskipun hanya dicantumkan did alam tajuk Catatan Budaya ataupun Keterangan, hal itu dapat mengingatkan para pengajar BIPA bahwa materi tentang aspek-aspek sosial budaya itu perlu disampaikan kepada para pembelajar BIPA agar mereka mengenal masalah-masalah sosial budaya Indonesia. Dengan pengenalan itu, diharapkan mereka dapat berkomunikasi secara baik dan benar dengan menggunakan bahasa Indonesia.

Berbeda dengan buku-buku BIPA yang lain, dalam buku yang berjudul Spoken Indonesiaan : A Course in Indonesian National Language yang ditulis oleh Anderson (Zulaeha 2016), aspek-aspek sosial budaya masyarakat Indonesia dicantumkan secara eksplisit sebagai materi ajar yang utama. Di dalam buku itu, informasi tentang aspekaspek sosial budaya yang dicantumkan meliputi jarak sosial (saling kenal atau tidaknya para peserta komunikasi), jenis kelamin, usia, status sosial, dan hubungan ekkeluargaan di antara para peserta komunikasi. Beberapa aspek sosial tersebut dianggap sebagai penentu yang penting dalam berkomunikasi dengan orang lain, terutama dalam memilih bentuk-bentuk ujaran yang sesuai dengan konteksnya, baik yang berupa konteks sosial maupun konteks budayanya. Dalam buku itu, diberikan pula gambaran tentang situasi yang menentukan ragam bahasa, dan juga lokasi pembicaraan, seperti di kantor pos, di rumah, di restoran, dan di pasar. Informasi tersebut selain dicantumkan sebagai materi pelajaran, juga disertai pula dengan

contoh-contoh penggunaannya. Bahkan, pembahasan menegnai hal itu dicantumkan di dalam bab tersendiri.

Aspek-aspek sosial budaya mempunyai peranan yang amat penting dalam pembelajaran BIPA. Peranannya itu terutama dapat menghindarkan pembelajar bahasa dari kemungkinan terjadinya benturan budaya (cultural shock) ketika berkomunikasi dengan penutur asli. Kecuali itu, dengan pemahaman terhadap aspek-aspek sosial budaya, pembelajar juga dapat mengetahui apakah unsur-unsur bahasa yang akan digunakannya itu dapat menyinggung perasaan orang lain atau mungkin bertentangan dengan norma-norma sosial budaya yang berlaku di masyarakat atau tidak. Dengan perkataan lain, pemahaman terhadap aspek-aspek sosial budaya itu dapat berperan dalam menanamkan tata krama (ungguh-ungguh) pada diri si pembelajar dalam berkomunikasi dengan penutur asli. Dengan mengetahui tata karama atau unggahungguh dalam berkomunikasi itu, pembelajar bahasa dapat berkomunikasi dengan menggunakan bahasa Indonesia secara baik dan benar. Di samping itu, pemahaman terhadap aspek-aspek sosial budaya tersebut secara umum juga dapat berperan menambah wawasan pengetahuan dan penghayatan para pembelajar BIPA terhadap berbagai aspek sosial budaya masyarakat Indonesia.

Wujud budaya yang ada di masyarakat terbagi atas tiga jenis, yakni gagasan, aktivitas, dan artefak (Koentjaraningrat 2015:15). Gagasan merupakan suatu wujud kebudayaan dari ide-ide, norma-norma, dan nilainilai. Aktivitas adalah wujud 
kebudayaan berupa kelakuan berpola dari manusia dalam masyarakat. Artefak merupakan wujud kebudayaan berupa benda-benda hasil karya manusia. Sementara itu, secara khusus budaya lokal diartikan sebagai ciri khas budaya yang dimiliki suatu masyarakat lokal. Budaya tersebut menjadi ciri khusus yang dimiliki suatu kelompok masyarakat, seperti rumah joglo, keris, sekaten, dugderan, ngaben, kirab, dan lain sebagainya.

Budaya dapat digunakan sebagai pendekatan dan materi dalam pembelajaran BIPA. Beberapa pengajar maupun praktisi BIPA telah melakukan kajian terhadap budaya guna menopang kebutuhan dalam pembelajaran. Terbukti dengan adanya beragam penelitian mengenai pemanfaatan budaya dalam pembelajaran BIPA, baik sebagai muatan dalam pembelajaran maupun materi pembelajaran (lihat Suyitno 2007; Siroj 2012; Sudaryanto 2015; dan Prasetiyo 2015).

\section{METODE PENELITIAN}

Metode yang digunakan dalam penelitian ini adalah deskriptif kualitatif. Penelitian ini dikaji melalui dua pendekatan penelitian, yaitu pendekatan teoretis dan pendekatan metodologis. Secara teoretis, digunakan pendekatan teori media pembelajaran. Sementara itu, secara metodologis digunakan pendekatan deskriptif kualitatif. Sugiyono (2011:14) menguraikan metode kualitatif digunakan untuk mendapatkan data yang mendalam, suatu data yang mengandung makna. Makna adalah data yang dijumpai dalam kenyataan dan bersifat pasti

136 | Jurnal Kredo Vol. 1 No. 1 Oktober 2017 yang merupakan suatu nilai dibalik data yang tampak. Sehubungan dengan hal tersebut dipilih pendekatan kualitatif deskriptif dimana yang dikumpulkan berupa pendapat, tanggapan, informasi, konsep-konsep, dan keterangan yang berbentuk uraian dalam mengungkapkan masalah.

Penelitian ini dilakukan selama tiga bulan. Penelitian ini dilakukan di Universitas Ezzitouna, Tunisia. Data dalam penelitian ini adalah bukti penggunaan media pembelajaran wayang mini, sedangkan sumber data penelitian ini adalah proses pembelajaran BIPA di Universitas Ezzitouna Tunisia. Subjek penelitian adalah pemelajar BIPA tingkat dasar (level A1). Teknik pengumpulan data dilakukan dengan teknik simak, catat, dan wawancara. Adapun interpretasi data dilakukan dengan paparan deskriptif secara informal.

Setelah data terkumpul, peneliti melakukan uji keabsahan data. Uji keabsahan data dilakukan dengan teknik triangulasi. Triangulasi menurut Moleong (2010:330) adalah teknik pemerikasaan keabsahan data yang memanfaatkan sesuatu yang lain di luar data itu untuk keperluan pengecekan atau sebagai pembanding terhadap data itu. Teknik triangulasi yang paling banyak digunakan ialah pemerikasaan melalui sumber lainnya. Untuk menetapkan keabsahan data diperlukan teknik pemeriksaan yang terdiri atas empat kriteria, yaitu derajat kepercayaan (credibility), keteralihan (transferability), kebergantungan (dependability), dan kepastian (confirmability). 
Uji keabsahan data dapat dilakukan melalui re-check (memeriksa kembali) temuan dan membandingkannya dengan berbagai sumber, metode, atau teori. Untuk itu, peneliti dapat melakukannya dengan cara 1) mengajukan berbagai macam variasi pertanyaan; 2) mengeceknya dengan berbagai sumber data; dan 3) memanfaatkan berbagai metode agar pengecekan kepercayaan data dapat dilakukan (Moleong 2010:332).

Setelah melakukan analisis data, peneliti kemudian melakukan interpretasi dan penyajian data. Interpretasi dan penyajian data dalam penelitian ini dilakukan secara paparan deskriptif. Sudaryanto (2015:241) menjelaskan bahwa penyajian data dapat dilakukan dengan dua cara. Dua cara penyajian data tersebut adalah sajian secara formal dan informal. Penyajian data secara formal dilakukan dengan menggunakan tanda dan lambang seperti tanda tambah (+), tanda kurang (-), tanda bintang $(*)$, tanda panah $(\rightarrow)$, tanda kurung biasa $(())$, tanda kurung kurawal $(\{\})$, dan tanda kurung siku ([ ]). Selain itu, ada juga lambang huruf sebagai singkatan nama seperti $\mathrm{S}, \mathrm{P}, \mathrm{O}, \mathrm{K}$; lambang sigma $\left(\sum\right)$ untuk satuan kalimat, dan berbagai diagram. Sementara itu, penyajian data secara informal dapat dilakukan dengan cara menggunakan kata-kata biasa. Penyajian tersebut berbentuk deskriptif dan menggunakan terminologi yang bersifat teknis. Adapun penyajian hasil analisis data dalam penelitian ini disajikan secara informal.

\section{HASIL DAN PEMBAHASAN}

\section{Wayang Mini dalam Pembelajaran Berbicara}

Wayang merupakan salah satu produk budaya yang khas dari Indonesia. Oleh sebab itu, wayang juga memiliki daya tarik bagi pemelajar BIPA di Universitas Ezzitouna, Tunisia. Pengajar dapat menggunakan wayang, baik kulit maupun golek sebagai media pembelajaran. Akan tetapi, ukuran wayang yang sesungguhnya terkadang menjadi kendala jika dibawa ke luar negeri. Oleh sebab itu, pengajar BIPA perlu memodifikasi wayang dengan bentuk berbeda, sehingga wayang dapat digunakan sebagai media pembelajaran di Universitas Ezzitouna, Tunisia.

Salah satu cara menghadirkan wayang di Universitas Ezzitouna Tunisia adalah penggunaan wayang mini. Pengajar BIPA dapat memanfaatkan kertas karton atau kardus bekas untuk membuat media wayang mini. Pertama, pengajar perlu mencari gambar tokoh-tokoh wayang Indonesia. Setelah itu, gambar tersebut dapat digunakan sebagai pola pada kertas karton atau kardus bekas. Meskipun sederhana, media tersebut sangat representatif untuk pembelajaran keterampilan berbicara. Di samping itu, media wayang mini tersebut juga dapat digunakan sebagai sarana pengenalan budaya.

Sarana diplomasi lain juga dapat dilakukan melalui media wayang mini. Wayang mini merupakan replika wayang kulit dari Indonesia. Wayang mini dapat dihadirkan dengan mudah di kelas 
BIPA Tunisia. Oleh sebab itu, wayang mini dapat digunakan sebagai media pembelajaran keterampilan berbicara/bercerita. Wayang mini berfungsi sebagai media yang dapat merangsang pemelajar bermonolog atau berdialog dengan teman. Pengajar perlu mempraktikkan penggunaan wayang mini kepada pemelajar terlebih dahulu. Setelah itu, pemelajar mulai praktik berdialog atau bermonolog sesuai langkah pembelajaran. Wayang mini tepat digunakan sebagai media pembelajaran menyimak-berbicara.

\section{Pembelajaran Keterampilan Berbicara dengan Wayang Mini di Universitas Ezzitouna, Tunisia}

Media wayang mini yang dituangkan dalam artikel ini secara khusus mengulas pembelajaran BIPA dengan tema jalan-jalan. Pada tahap awal, pemelajar mendapatkan sajian dialog wayang mini dari pengajar. Kegiatan ini merupakan bentuk keterampilan menyimak dalam pembelajaran BIPA. Setelah itu, pengajar dan pembelajar dapat bertanya jawab mengenai kegiatan jalan-jalan dengan media wayang mini. Pengajar bertanya sebagai tokoh wayang yang sedang dipegang, sedangkan pemelajar menjawab pertanyaan pengajar atas nama tokoh wayang yang sedang dipegang pula. Kegiatan berikutnya, tiap pemelajar saling berdialog menggunakan wayang mini dengan tema jalanjalan. Pada puncak pembelajaran, pemelajar praktik mendalang dengan dialog sederhana antara dua tokoh pewayangan. Tema dialog tersebut yaitu jalan-jalan. Adapun langkah pembelajaran dengan media wayang mini dapat dilihat secara rinci pada bagian lampiran.

138 | Jurnal Kredo Vol. 1 No. 1 Oktober 2017
Adapun tema pembelajaran menggunakan wayang mini cukup beragam. Pengajar dapat menggunakan wayang mini pada tema pembelajaran menyapa, berkenalan, keluarga, hobi, jalanjalan, dan lain sebagainya. Dalam pembelajaran menyimak-berbicara bertema jalan-jalan, pemelajar dikenalkan terlebih dahulu tentang wayang sesungguhnya di Indonesia. Apabila mereka berwisata ke Indonesia, mereka akan menemukan wayang. Setelah itu, pengajar praktik mendalang sederhana dengan tema jalan-jalan. Dialog disesuaikan dengan kemampuan penguasaan kosakata pemelajar. Setelah itu, pemelajar BIPA berlatih menggunakan wayang mini untuk berdialog maupun bercerita. Dalam proses pembelajaran tersebut, pemelajar tidak hanya memiliki keterampilan menyimak-berbicara. Akan tetapi, mereka juga memiliki pengetahuan tentang budaya Indonesia melalui diplomasi budaya menggunakan media wayang mini. Kondisi tersebut sejalan dengan berbagai temuan penelitian tentang pembelajaran BIPA berbasis budaya lokal (lihat Sudaryanto 2015; Widianto 2016; Nugroho 2017; dan Istanti 2017).

Sebagai gambaran nyata implementasi pembelajaran keterampilan berbicara menggunakan media wayang mini, berikut contoh langkah pembelajaran yang dapat dilakukan.

\section{(1)Kegiatan Awal}

(1) Pengajar membuka kelas dengan memakai blangkon dan syal tenun sambil memegang dua wayang mini; 
(2) Pengajar bercerita tentang kegiatan di luar rumah (melanjutkan tema kegiatan sehari-hari di dalam rumah), salah satunya adalah jalanjalan ketika hari libur;

(3) Kemudian pengajar menceritakan pengalaman jalan-jalan di Indonesia. Turis akan menemukan blangkon, tenun, wayang, dan lainnya;

(4) Pengajar memberikan contoh memainkan wayang mini secara sederhana dalam bentuk dialog sapaan, namun dikemas seolah-olah pertunjukan wayang di Indonesia

\section{(2)Kegiatan Inti}

(1) Pengajar melanjutkan memainkan wayang dengan tema dialog jalan-jalan;

(2) Pemelajar mulai menyimak dengan saksama dan mencatat beberapa kosa kata baru;

(3) Pengajar dan pemelajar mereviu kosakata baru di papan tulis;

(4) Pengajar membagikan wayang satu persatu untuk pemelajar;

(5) Pemelajar diberitahu nama wayang yang sedang dipegang (sesuai nama-nama tokoh pewayangan seperti Arjuna, Srikandi, Rama, Shinta, dll);

(6) Pengajar memainkan satu wayang untuk digunakan sebagai alat bertanya kepada pemelajar tentang pengalaman/rencana jalanjalannya;

(7) Satu persatu pemelajar menjawab pertanyaan pengajar dengan memainkan wayang miliknya (bermain suara dan mimik juga);

(8) Setelah pemelajar menjawab pertanyaan sederhana satu persatu, mereka menyusun garis besar cerita jalan-jalan yang akan/telah mereka lakukan;

(9) Pemelajar berdialog menggunakan wayang mini dengan teman di dekatnya tentang tema jalan-jalan;

(10) Pengajar

membagikan satu wayang lagi untuk setiap pemelajar yang kemudian digunakan untuk praktik mendalang/mendongeng;

(11) Pemelajar menyusun garis besar dialog sederhana dengan tema jalan-jalan;

(12)

Pemelajar berlatih memainkan dialog wayang mini dengan tema jalan-jalan berdasarkan tokoh wayang yang dimiliki;

(13) Beberapa pemelajar dapat menunjukkan kegiatan mendalang/mendongengnya di depan teman-temannya;

\section{(3)Kegiatan akhir/penutup}

(1) Pemelajar memberikan apresiasi penampil dengan memilih penampil terbaik, kemudian pengajar memberikan reward berupa hadiah; 
(2) Pengajar dan pemelajar mengulang kembali beberapa kosakata kunci dalam tema jalan-jalan untuk memfasihkan pengucapannya;

(3) Pengajar kembali bertanya menggunakan wayang mini secara singkat kepada para pemelajar dengan dialog tentang rencana jalan-jalan ke Indonesia sebagai bentuk evaluasi;
(4) Pengajar pembelajaran menutup tampilan seperti penutupan pertunjukan wayang.

Adapun aspek yang dinilai dalam pembelajaran keterampilan berbicara menggunakan wayang mini dapat dilihat dalam tabel berikut.

Tabel 2. Aspek dan Indikator Penilaian

\begin{tabular}{|c|c|c|c|}
\hline $\begin{array}{c}\text { Aspek } \\
\text { penilaian }\end{array}$ & Indikator & Bobot & Skor \\
\hline Ide & $\begin{array}{l}\text { 1.Memuat lebih lebih dari lima } \\
\text { kegiatan dalam jalan-jalan (10) } \\
\text { 2.Memuat empat kegiatan dalam } \\
\text { jalan-jalan (7) } \\
\text { 3.Memuat tiga kegiatan dalam jalan } \\
\text { jalan (5) } \\
\text { 4.Tidak memiliki ide (0) }\end{array}$ & 5 & 50 \\
\hline Kelancaran & $\begin{array}{l}\text { 1.Penyampaian kalimat runtut } \\
\text { disertai konjungsi yang baik dan } \\
\text { benar (10) } \\
\text { 2.Penyampaian kalimat runtut tanpa } \\
\text { disertai konjungsi (7) } \\
\text { 3.Penyampaian kalimat tidak runtut } \\
\text { dan atau tidak disertai konjungsi } \\
\text { (5) } \\
\text { 4.Penyampaian kalimat tidak dapat } \\
\text { dipahami (0) }\end{array}$ & 3 & 30 \\
\hline Kefasihan & $\begin{array}{l}\text { 1.Fasih dalam mengucapkan semua } \\
\text { kosakata (10) } \\
\text { 2.Mengucapkan kurang dari lima } \\
\text { kosakata secara tidak fasih (7) } \\
\text { 3.Mengucapkan lebih dari lima }\end{array}$ & 2 & 20 \\
\hline
\end{tabular}

140 | Jurnal Kredo

Vol. 1 No. 1 Oktober 2017 


\begin{tabular}{|l|l|l|l|}
\hline & $\begin{array}{l}\text { kosakata secara tidak fasih (5) } \\
\text { 4.Semua kosakata tidak diucapkan } \\
\text { berdasarkan pelafalan bahasa } \\
\text { Indonesia (0) }\end{array}$ & & \\
\hline Total nilai tertinggi & 100 \\
\hline
\end{tabular}

\section{SIMPULAN}

Ada beberapa manfaat penggunaan media pembelajaran wayang mini untuk pembelajaran BIPA di Universitas Ezzitouna Tunisia. Manfaat penggunaan media pembelajaran tersebut yaitu

1) pembelajaran lebih komunikatif dan menarik;

2) meminimalkan translasi/terjemah dalam pembelajaran;

3) menguatkan ingatan pemelajar BIPA terhadap suatu kosakata maupun konsep karena media bersifat ikonis;

4) pemelajar lebih banyak beraktivitas dalam mengeksplorasi media;
5) bahan ajar menjadi lebih bermakna; dan

6) sarana diplomasi budaya Indonesia.

Di samping itu, ada beberapa rekomendasi yang dapat disampaikan. Pertama, pembelajaran BIPA di Universitas Ezzitouna Tunisia perlu ditunjang dengan media pembelajaran yang representatif. Kedua, pengajar BIPA perlu mengeksplorasi media pembelajaran yang mampu menguatkan interpretasi pemelajar tentang Indonesia, agar diplomasi budaya juga berjalan dengan baik. Ketiga, media pembelajaran harus dimanfaatkan untuk mengarahkan pemelajar lebih aktif di dalam kelas. Terakhir, media pembelajaran yang digunakan harus bernuansa khas budaya Indonesia.

\section{DAFTAR PUSTAKA}

Alwasilah, A. Chaedar dan Senny Suzanna Alwasilah.2008. Pokoknya Menulis: Cara BAru Menulis dengan Metode Kolaborasi. Bandung: Kiblat.

Brown, H. Douglas. 1980. Principles of Language Teaching and Learning. New Jersey: Prentice Hall Inc.

Hazeau. 1897. Bijdrage Tot De Kennis Van Het Javaansche Toonel. Leiden: E.J. Brill.

Istanti, Wati. 2017. Media Kliping Cerita Rakyat Indonesia Sebagai Sarana Menumbuhkan Pemahaman Lintas Budaya bagi Pemelajar Tingkat Madya. Prosiding PITA BIPA III. Universitas Katolik Indonesia Atmajaya. 
Istanti, Wati. 2017. Strategi Pengajaran bahasa Indonesia bagi Penutur Asing di Luar Negeri. Prosiding SEMAR (Seminar Kepakaran) BIPA: Volume 1. APPBIPA Jawa Tengah.

Krashen, Stephen D. dan Tracy D. Terrell. 1985. The Natural Approach Language Acquisition in the Classroom. New York: Pergamon Press.

Koentjaraningrat. 2015. Kebudayaan Mentalitas dan Pembangunan. Jakarta: Gramedia.

Kusmiatun, Ari. 2015. Mengenal BIPA (Bahasa Indonesia Bagi Penutur Asing) dan Pembelajarannya. Yogyakarta: K-Media.

Moleong, Lexy J. 2010. Metodologi Penelitian Kualitatif Edisi Revisi. Bandung: Remaja Rosdakarya Offset.

Nugroho, Yusro Edy. 2017. "Model Pembelajaran Tata Bahasa Indonesia bagi Penutur Asing Berbasis Sosiokultural”. Prosiding PITA BIPA III. Universitas Katolik Indonesia Atmajaya.

Prasetiyo, Andika Eko. 2015. Pengembangan Bahan Ajar BIPA Bermuatan Budaya Jawa Bagi Penutur Asing Tingkat Pemula. (Skripsi). Universitas Negeri Semarang.

Rahmina, Iim. 2002. Strategi Belajar Mengajar BIPA. Bandung: Jurusan Pendidikan Bahasa dan Sastra Indonesia.

Siroj, Badrus. 2012. Pengembangan Model Integratif Bahan Ajar Bahasa Indonesia Ranah Sosial Budaya Berbasis ICT bagi Penutur Asing Tingkat Menengah. (Tesis). Jurusan Sastra Indonesia Universitas Negeri Semarang.

Stern, H.H. 1983. Fundamental Concepts of Language Teaching. Oxford: Oxford University Press.

Sudaryanto, 2015. Metode dan Aneka Teknik Analisis Bahasa: Pengantar Penelitian Wahana Kebudayaan Secara Linguistis. Yogyakarta: Sanata Dharma University Press.

Sudaryanto. 2015. Pengenalan Budaya Indonesia bagi Siswa BIPA Tiongkok Melalui Materi Ajar Nasi Kuning dan Perkedel: Kasus di Universitas Kebangsaan Guangxi. Prociding of International Conference: Volume 2. Universitas Islam Sultan Agung. Hal. 173-178.

Sudjana, Nana dan Ahmad Rivai. 2010. Media Pengajaran. Bandung: Sinar Baru Algensindo.

Sugiyono. 2011. Metode Penelitian Pendidikan: Pendekatan Kuantitatif, Kualitatif, dan $R \& D$. Bandung: Alfabeta.

Sutirman. 2013. Media \& Model-model Pembelajaran Inovatif. Yogyakarta: Graha Ilmu.

Suyitno, Imam. 2007. Pengembangan Bahan Ajar Bahasa Indonesia untuk Penutur Asing (BIPA) berdasarkan Hasil Analisis Kebutuhan Belajar. Wacana Vol.9 No.1, April 2007 (62 - 78).

Widianto, Eko. 2015. Pola Penggunaan Bahasa dalam Pembelajaran Bahasa Indonesia Bagi Penutur Asing di Universitas Negeri Semarang. Prosiding

142 | Jurnal Kredo Vol. 1 No. 1 Oktober 2017 
Seminar Bahasa Asing: Kini dan Nanti. Seminar Bahasa Asing, Universitas Negeri Semarang.

Widianto, Eko. 2016. Pilihan Bahasa dalam Interaksi Pembelajaran Bahasa Indonesia bagi Penutur Asing. Jurnal Seloka. Volume 5 (2) (2016). Halaman 124-129.

Widianto, Eko. 2016. Budaya Lokal Joglosemar dalam Pembelajaran MembacaMenulis Bagi Pembelajar BIPA Tingkat Dasar. Prosiding SEMAR (Seminar Kepakaran) BIPA: Volume 1. APPBIPA Jawa Tengah. Hal 102-108.

Winkel, W.S. 1987. Psikologi Pengajaran. Jakarta: Gramedia.

Zulaeha, Ida. 2016. Pengembangan Kemampuan Menulis Kreatif dalam Konteks Multikultural Siswa SMP dengan Model Inkuiri Sosial. Semarang: UNNES Press. 